It will, therefore, of itself, cleave in the way described, and the flow of water will thereby be hindered at the constrictions, and aided at the places of bulging out. Thus lines of easiest flow will be set up, which in their turn will determine the furrows on the back of the wave. The fringe of drops is due to the splitting in a similar manner of the cylindrical jets shot out from the places of bulging, where the flow is aided. Indeed, much of the seething at the edge of a wave is, I think, attributable to the breaking up of such jets in this manner. In the case of the minute phenomenon of a drop-splash, I have been able, in some degree, to bring this explanation to the test of measurements, which, so far as they go, quite confirm it. The regularly-toothed edge of a spot of candle-wax that has fallen on a cold object, affords in a permanent form a familiar illustration of the same action.

Clifton College, Bristol, June 20

A. M. WORTHINGTON

\section{THE SEAL ISLANDS OF ALASKA 1}

$\mathrm{T}$

$\mathrm{EN}$ years have only just elapsed since the Government of the United States of America obtained by treaty the territory of Alaska, including the seal islands situated off its coast in the Bering Sea, and at that time although the sealskin trade occupied thousands of hands, and had done so for at least a century previous, yet next to nothing was known of the animal producing the skins, and there was not, even in the museum of the Smithsonian Institution, a perfect skin and skeleton thereof. This state of things has happily. now vanished, and through the joint action of Prof. Spencer Baird and the Secretary of the Treasury of the United States, Mr. Henry W. Elliott, was enabled to visit the Pribylov Islands in 1872 , and we cannot but admire the zeal and energy which enabled him to reside in these dreary and desolate places all through the seasons of 1872 to 1874 inclusive. While a brief digest of Mr. Elliot's notes were published in I874, it is only now that he has been enabled to publish a complete monograph on the subject, an emended copy of which, reprinted from the Report on the Fishery Industries of the Tenth Census at Washington in this year, is now before us. It forms a quarto volume of some 176 pages, and is illustrated by two maps and twenty-nine plates of subjects from the author's pencil. The writer's opportunities for observation, it will be noticed, were especially good. The previous observations of Stellar and others left much to be desired. The geographical distribution of the Arctic fur seal (Callorhinus) is very peculiar. In the Arctic waters of the Atlantic they have not been found, in the corresponding waters of the Pacific they are virtually confined to four islands in Bering's Sea, namely St. Paul and St. George of the tiny Pribylov group, and Bering and Copper Islands of the Commander group. On the former two they swarm. On the latter two, though the larger in area, the seals do not occur in such quantities. It seems impossible to avoid the reflection here as to the waste of fur seal life in the Antarctic regions, and along the coasts of South America, from which, as a centre, the Arctic forms, probably, originally came. Not a century ago the fur seals rested on the Falkland Islands in millions for hundreds that are to be found there now, and it seems hopeless to expect that a British parliament could, with all its many labours, trouble itself to frame regulations, such as the Russians and Americans have done, with the object of repeopling, even in time, these splendid breeding-grounds which, on the Falklands, lie in the very track of commerce, and which, unlike the Alaskan Islands, have beautiful and safe harbours.

The Pribylov Islands were discovered by the hardy navigator whose name they bear, in 1786 , and one of the islands is called after his sloop, the St. George. He took possession in the name of Russia. Almost striking against the island in a fog, the sweet music to his ears of

" "A Monograph of the Seal Islands of Alaska," by Henry W. Elliott. Reprinted, with Additions, from the Report on the Fishery Industries of the Tenth Census (U.S. Commission of Fish and Fisheries). Washington, February, I882. numerous seal rookeries was wafted towards him. For a little time he kept his secret ; but he was soon watched, and his treasure had to be shared with others. These islands lie in the heart of Bering Sea; they are just far enough south to be beyond the reach of permanent ice-floes, upon which the Polar bears could have reached them. Fog banks shut out the sun nine days out of ten during summer, and the breeding season. By the middle of October strong, cold winds from the Siberian Steppes sweep across them. By the end of January great fields of sludgy, broken ice bear down on them; and from December to May, or June, they lie ice-bound. It is owing to this constant, cold, moist, shady, gray weather, that these islands are frequented by such millions of the fur seals. Let the sun but shine out, and the temperature rise to $60^{\circ} \mathrm{F}$, or $64^{\circ} \mathrm{F}$. in the shade, and both seals and natives are at once incommoded by the glare and heat. During the winter of $1872-73 \mathrm{Mr}$. Elliott, while watching with all the impatience which a man in full bealth and tired of confinement can possess, to seize every opportunity upon quiet intervals between the storms of sleet, in order to make a short trip for exercise, only got out three times, and then only by the exertion of great physical energy. On one occasion the temperature sank to $-4^{\circ}$, and the wind velocity, as recorded by one of the Signal Service anemometers, was at the rate of 88 miles per hour. This storm lasted for six days. The average summer temperature is between $46^{\circ}$ and $50^{\circ} \mathrm{F}$. in ordinary seasons. The cloud effects are, as might be anticipated, something wonderful, but the aurora is scarcely to be seen. The islands are of volcanic formation; their vegetation seems interesting, and algæ (seaweeds) seem to abound. This is the weakest part of the author's report, and it would be well worthy of the Smithsonian Institute to have the whole flora of these islands carefully investigated. Only a few very hardy vegetables are raised on St. Paul's. As yet, rats seem not to have landed on the islands, though mice have become troublesome, and the cats brought to keep the mice in order, have by inordinate indulgence in meat (seal) eating, become wonderfully altered; they are described as "stubby balls," having become thickened, short, losing the greater portion of their tails (in the second and third generations), and their voices are altered into a prolonged, fearful cry, that surpasses anything ever heard in these countries. So bad is this caterwauling, that it even at times arouses the wrath of the sluggish Aleutians. Foxes and lemmings abound on St. George ; the latter are not found at St. Paul's. Birds abound, and though fishes are scarce, invertebrate life in the waters of the group seems abundant. The " natives" of the island were about 400 in number in 1880 , of whom some eighteen were whites (Russian), and the rest Aleutians. The births never equalled the deaths, but they are constantly being recruited by the Alaskan Commercial Company. Now-a-days the people are comfortably housed and well clothed. Seal meat is their staple food; and by the regulation of the Treasury they can kill, every autumn, an average of twenty-three to thirty young seals for each man, woman, and child in the settlement. As each pup averages ten pounds of good meat, this would show an average of about 600 pounds of flesh meat for each. To this diet they add butter, sweet crackers, and sugar. They are passionately fond of butter. No epicure could appreciate good butter more than these people, and the sweetest of all sweet teeth are to be found in the jaws of an Aleut. The Company allows them fairly liberal supplies of these, also rice and tobacco. As an illustration of the working ability of the natives on the seal grounds, the following shows the actual time occupied by them in finishing up the three seasons' work which Mr. Elliott personally supervised on St. Paul's Island.

In 1872,50 days' work of 7 I men secured 75,000 skins.

$\begin{array}{lllll}\text { In } 1873,40 & , & 7 \mathrm{I} & , & 75,000 \\ \text { In } 1874,3^{6} & , & 84 & , & 90,000\end{array}$ 
'This shows the increased ability and consequent celerity of action among the natives.

Here it may be mentioned that by an Act of Congress the exclusive right of taking a certain number of fur seals every year for a period of twenty years on these islands was granted to the Alaskan Commercial Company of San Francisco, subject to certain reservations and conditions. The Company seem to have done far more than they were actually by law required, and the benefit to the people has been no less great than to the Company; and where it was simply impossible under the old state of things to collect the lawful quota of 100,000 seals' skins annually in less than from three to four working months, it is now done by the same amount of hands in less than thirty days, and so the whole of the skins are preserved at their prime, and it is rare that any of them are unfit to be sent to London, whereas in comparatively recent years, often as many as three-fourths were rejected; comment on such an altered state of things is needless. Here it may be interesting to note that almost all the raw seal hides are sent to London, from whence, when dressed, they are distributed all over the civilised world where furs are worn. Our reader will surely know that the sealskins as worn by the seals and as offered for sale by the furrier are very different-looking objects. Instead of the sleak, glossy coats familiar to us, the sealskin when on its own owner's back is a very unattractive thing, the fur not being visible, but hidden away under a coat of stiff overhair, which is of a dark gray brown or grizzled colour. Not only is this hair removed, but the whole fur is dyed.

The seal life on the Pribylov group consists not only of the fur seal (Callorhinus ursinus), but also of the sea lion Eumetopias Stelleri, the hair seal (Phoca vitulina). and the walrus (Odotanus obesus). Of these it is only the first that is of any commercial value; but in this work we have some very interesting sketches of the life and manners of the others, and some very characteristic portraits. As our space will not allow us to refer in detail to these, we may here mention the fine figure of an old male walrus, being a life study, forming Plate $2 \mathrm{I}$, and the figures of the sea lions on Plate 16 . The life studies of the common hair seal on Plate 4 are also very excellent ; this animal, so common in the Atlantic, would appear to be rare in the North Pacific. Although the skin of the sea-lion has little or no commercial value, yet to the natives it is most valuable; it supplies them not only with its hide and flesh, but they also utilise its fat, sinews, and intestines; its very lip bristles are in great demand in China for pickers to the opium pipes, and for several ceremonies peculiar to the joss houses. The walruses are of little value unless for their hides; these are used for covering the frames of boats, and when the latter are thoroughly and constantly attended to they form the best species of lighter that can be used on the islands, standing more thumping and pounding than any sort of a wooden boat or even than a corrugated iron lighter.

It is, however, the history of the fur seal that will chiefly interest the readers of this volume. It repairs to these islands to breed and to shed its hair and fur, in numbers that seem almost fabulous. It seems to be an animal of wonderful instinct; indeed, our author thinks that few, if any, creatures in the animal kingdom exhibit a higher order of instinct. A male, when in his prime, about 6 or 7 years of age, will measure $6 \frac{1}{2}$ to $7 \frac{1}{4}$ feet in length from the tip of his nose to the end of his little tail, and will weigh from 400 to 600 pounds. Its muzzle and jaws are about the same size and form as those of a full blooded Newfoundland dog, only the lips are pressed against one another as in man; on either side of the muzzle are an expressive pair of large bluish hazel eyes. In one of the plates there is a very excellent portrait by the author, of an old male. When the fur seal moves on land, it may be almost said to step with its fore feet, but it brings up the rear of its body in a quite different style, for after every second step ahead with the anterior limbs, it will arch its spine, and in arching it drags and lifts up and brings forward the hind feet to a fit position under its body, giving it, in this manner, fresh leverage for another movement forward by the fore feet, in which movement the spine is again straightened out. If it be frightened, its abandons this method. "It launches into a lope, and actually gallops so fast, that the best powers of a man in running are taxed to head it." This rapid progress it can only keep up for some thirty or forty yards at most, then it sinks to the earth, gasping and breathless. The adult males are always the first to arrive on the sealground, which has been deserted by all of them since the close of the preceding year. These arrivals begin about May I. Not the oldest, but the most ambitious, land first. Up to June I more seals arrive, but about this period the seal weather begins-foggy and moist ; and as the gray banks roll up and shroud the islands, the bull seals swarm out of the depths by thousands, and take up advantageous positions. The labour of locating and maintaining a position on the rookery is a terribly serious business for the late-coming males, as it is throughout all the time to those males that occupy the water-line of the breeding-grounds. A constantly sustained fight between the new comers and the occupants goes on morning, noon, and night without cessation, frequently resulting in death to one, and even to both the combatants. This fighting is done with the mouth. The sharp, canine teeth, tear out great masses of the skin and blubber. One old veteran, specially watched, took up his position on the water-line early in May. He had to fight from forty to fifty desperate battles; and when the fighting seaso $n$ was over he was there, covered with scars, and frightfully gashed, raw, festering, and bloody, with one eye gouged out, but lording it still bravely over his harem of some fifteen or twenty females. These seals are profound sleepers, so much so that one, cautiously keeping to the leeward, and stepping softly, would find it easy to approach near enough to pull the whiskers of any old male; but on the first touch the trifler must be prepared to jump back with electrical celerity, if he has any regard for the sharp teeth and tremendous shaking which would await him. On young seals the trick may be played with impunity, but to the great terror and confusion of the little sleepers. While the females and young have but one note, a hollow prolonged bla-a-ting call, addressed to their young: the bulls have the power of uttering four distinct calls or notes. They seem to suffer misery from a comparatively low degree of heat. From the time of the males landing, until the close of the season-about three months - they never leave the stations they have secured for a single moment, and of necessity they abstain during all this time from food of any kind, or water. It is no wondcr, therefore, that after such a fast they return to the sea mere bony shadows of what they were.

About the middle of June the females arrive, and, bad as the fighting among the males has been up to this to secure good stations on the land, it is now ever so much worse for the possession of the cows. These latter are much smaller and more lithesome than the males, seldom over 4 to $4 \frac{1}{2}$ feet in length. Their heads and eyes are exceedingly beautiful ; their expression is gentle, intelligent, and attractive. The females land on the "rookeries" for the purpose of gestation, and the young are born very soon after the arrival of the females. The females are received by the males on the water-line stations with attention; they are alternately coaxed and asked up on the rocks, as far as these beach-masters can do so, by chuckling, whistling and roaring, and once up they are immediately under the most jealous supervision; but owing to the covetous and ambitious nature of the bulls which occupy those stations to the rear of the water-line ones and some 
way back, the little cows have a hard time of it at the first and when they are few, for no sooner is one pretty creature fairly established in the station of male number one, who has got her there, than he perhaps sees another of her style in the water from whence she has come, and he devotes himself to coaxing the later arrival by the same winning methods so successful before; whereupon bull number two, one station in the rear, observing bull number one to be off guard, reaches out with his long, strong neck, picks up the passive cow by the scruff of her neck, just as a cat does a kitten, and deposits her upon his ground; and this will happen again and again until the little cow will finally find herself several stations back. Her last lord not being exposed to the same temptations as lie on the water level, gives her such care that not only could she not leave if she wished, but no other bull gets a chance of seizing her. When the females have all landed and the harems are full, it would seem that those nearest the water may contain on an average from fifteen to twenty females, those in the rear from five to twelve. The courage of the fur seal is of the highest order. As regards man, it is invariably of a defensive character. Though always on the defensive, he never retreats, but he will not attack ; the cows, however, are easily frightened and are timorous. Shortly after the females are landed, the young are born; they are for the first three months of a jet black colour, are about fourteen inches long, and weigh about four pounds. It would seem that they are nursed only every second day, the mothers going off to the fish grounds to get a supply of food, but they may also return to suckle their young at night. When returning in the daytime, each mother at once recognises her own young, though there may be thousands upon thouands all together blaating at once. Before entering into such a crowd, the mother stops and calls out, just as a sheep does for a lamp, and out of all the din she then recognises her offspring's voice, and makes direct for it ; but it would seem that the young ones do not of ten know their own mothers.

Early in August the young seals, now about six weeks old, are taught to swim. If dropped into deep water about this period down goes their bullet-like head, and they are drowned; at first they try their skill in the shallow pools, for a week or two they only flounder about, thrashing the water as little dogs will do. When for the first time they are well launched out they soon turn to the shore, and if by some receding wave they should be left high and dry, they will crawl away for a little distance and, quite exhausted, will coil themselves up to take a short recuperative nap, and then to the swimming lesson again. Once boldly swimming they seem to fairly revel in it. The parents do not in the slightest degree supervise or direct the young in swimming. The young shed their black coat about the middle of October; the second or sea-going jacket, does not at first vary in colour between the sexes, nor does a pronounced difference take place until after the third year. The females bear their first young when they are three years old, and the period of gestation lacks only a few days of a year.

The great herds of "bachelor" seals, numbering perhaps one-third to one-half of the whole aggregate of the 5,000,000 seals known to the Pribylov group, are never allowed under the pain of death to put their flippers on or near the rookeries. These are the seals of most importance to commerce, for with the exception of a few thousand young ones and an odd old male, these are the only ones slaughtered for their hides. They locate them in immense tracts, mostly away from the rookeries, but sometimes the road to these will pass along or through a rookery, where, as Iong as the bachelors keep to the main road, they are never molested; but if they pry about, it is all over with them, for they are literally torn to pieces. These bachelors are wonderfully gentle, but they are possibly the most restless animals in creation, they never seem quiet, not even in their sleep, they do not fast, as they constantly leave the land for the sea, though this at irregular periods depending a good deal on the weather; on land they sport and roll about as if in perfect enjoyment, curling and uncurling themselves, in fact they seem to be surcharged with a quite joyous life, but when in play they never grovel or bite or seem to show even an angry feeling. It is we have seen very different with them when they are a little older and begin to take upon themselves the cares of a harem. These seals pass a deal of their time in the water, where their gambols are truly wonderful, and the time they can remain under water is, Mr. Elliott writes, "past belief." They are readily, when on land, classified as to age. They shed their fur and hair during August. Passing over a detailed and well illustrated account of the various rookeries, carefully calculated as containing some $3,193,042$ breeding seals and their young in 1873, and of non-breeding seals over $\mathbf{r}, 500,000$, and the speculations as to the vast amount of fish consumed by this immense army, we have to notice briefly the chapter on the taking of the seals. Except for food, none but the "bachelors" are slaughtered when their furs are in good trim : the natives get between a herd and the sea, and then gently drive it up to a slaughtering station. In cool and moist weather the seals can be safely moved along at the rate of half a mile an hour; on firm grassy ground three or four men can secure and guide as many as a thousand seals at the same time. They are permitted frequently to halt, rest, and cool, as over heating injures their fur, and so on they go to death, and to supply with their hides the markets of the world. They never show fight, and are as docile as a flock of sheep; the bull seals on the contrary will fight rather than endure the panting torture of travel, so that if any of them get mixed up with a herd of bachelors they are easily let drop out; their fur is of no value. On arriving at the slaughter places the herd is allowed to cool, and then the killing begins ; the labour of skinning is severe and trying even to experts; the hide has to be taken off at once. The skins are taken from the field to the salt-house, where they stay for two or three weeks, being pickled; after this they are taken and rolled into bundles of two skins in each package, with the hairy sides out and lightly corded. In this state they go by steamer to San Francisco, where they are counted for the tax, and from thence they are shipped to London.

In a series of illustrative and supplemental notes to this volume, there are a number of very interesting details as to the Russian Seal Islands; as to the Fauna and Flora of the Priblyov Group; a digest of the data in regard to the fur seal rookeries of the South Atlantic and Pacific, and the number of skins taken therefrom. There is a translation of Veniaminov's account of the Russian seal industry at the Priblyovs, 1842 ; a meteorological abstract for the months from September, 1872, to April, I873, which was an unusually severe winter; and a history of the organisation and regulations of the Alaskan Commercial Company, under whose excellent management the sealskin trade is now carried on. In concluding a necessarily somewhat brief notice of this excellent monograph, we would congratulate $\mathrm{Mr}$ Commissioner Spencer Baird on being the means of obtaining for men of science and of commerce so much valuable information, and we can scarcely give too much praise to Mr. Henry M. Elliott for his most artistic and praiseworthy history of the most interesting of all Pinnipeds.

\section{A DYNAMOMETER FOR ALTERNATING CURRENTS OF MODERATE STRENGTH}

$T \mathrm{HE}$ object of this instrument, which I had the pleasure of bringing before the Physical Society at their Oxford meeting, is chiefly medical. But it occurred to 